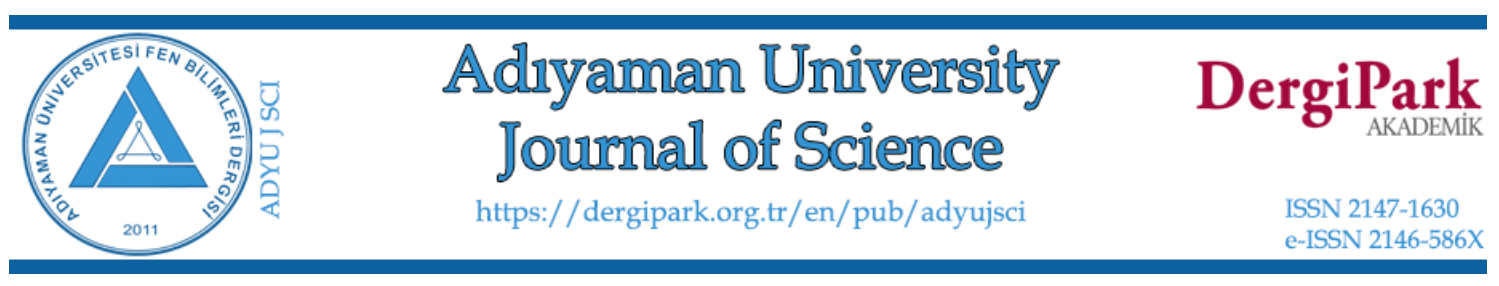

\title{
Diastereomeric Separation of a Novel Chalcone Derivative by Chiral HPLC
}

\author{
Ergin YALÇIN* ${ }^{1,2}$ \\ ${ }^{1}$ Iskenderun Technical University, Department of Engineering Basic Sciences, \\ Hatay,Turkey,ergin.yalcin@iste.edu.tr,ORCID:0000-0003-3710-7242 \\ ${ }^{2}$ ISTE Centre for Science and Technology Studies and Research (ISTE-CSTSR), \\ Iskenderun, Hatay, Turkey
}

$\begin{array}{lll}\text { Received: } 12.05 .2021 & \text { Accepted: } 31.05 .2021 & \text { Published: } 30.06 .2021\end{array}$

\begin{abstract}
In this study, a facile and versatile procedure for the synthesis of a chalcone derivate that a functionalized (E,Z)-2-(4-aminobenzylidene)acenaphthylen-1(2H)-one, 4 was synthesized and also characterized by using FT-IR, NMR and MS. A new HPLC method for the separation of its diastereomers was developed by using a chiral column that contains the amylose tris(3,5dimethylphenylcarbamate) as a chiral selector since it is effective, reproducible and can be used for preparative purposes. High percentage recovery claims that the presented method was not affected by the impurities in the biological media. RSD\% values for the repeatability studies suggest that the optimized method was highly precise and reproducible which is very important for these promising advances, chalcone-based science is expected to be applied in drug discovery.
\end{abstract}

Keywords: Chalcone; Diastereomeric separation; Acenaphtenone; Chiral column; HPLC.

\section{Kiral HPLC ile Yeni Bir Kalkon Bileşiğinin Diastereomerik Ayrılması}

Öz

Bu çalışmada (E,Z)-2-(4-aminobenziliden)asenaftilen-1(2H)-on, 4 bileşiği kolay ve hızlı bir metodla sentezlenip FT-IR, NMR ve MS kullanılarak karakterize edilmiştir. Bileşiğin diastereomerlerinin ayrılması için etkili, tekrarlanabilir, preparatif amaçlar için uygun amiloz 
tris(3,5-dimetilfenilkarbamat) kiral seçici kolon kullanıldığı bir HPLC metodu geliştirilmiştir. Yüksek geri kazanım oranı bileşiğin biyolojik ortamdaki safsızlıklardan etkilenmediğini göstermektedir. Tekrarlanabilirlik ile ilgili çalışmalarda \% BSS değerleri, optimize edilen metodun kalkon temelli bileşiklerin yer aldığı ilaç geliştirme çalışmalarında yüksek hassasiyet ve tekrarlanabilirlik değerleri ile kullanılabileceğini göstermiştir.

Anahtar Kelimeler: Kalkon; Diastereomerik ayrım; Asenaftenon; Kiral kolon; HPLC.

\section{Introduction}

Chalcones are biologically important compounds bearing in the scaffold 1,3diarylpropenones. They have attracted much interest due to the several biological activities including antiproliferative, antioxidant, anti-inflammatory, and anticancer effects on the important areas of ongoing research in medicine and molecular biology [1-3]. Apart from the biological activities of chalcones, chalcone-types compounds such as bichalcones, dihydrochalcones, and fused chalcones are being used concerning nonlinear optics, photorefractive polymers, holographic recording materials, and fluorescent probes for the sensing of any chemical species in media [4-5]. The chalcone type compounds may exist in two diastereomeric forms, $Z$ and $E$, the $E$ isomer is the most thermodynamically stable and lower in energy because diaryl groups are found as far away from one another as possible and are arranged on the opposite side of the double bond.

HPLC with a chiral stationary phase (CSP) is very useful tool for the separation of the enantiomers of the chiral molecules since it is effective, reproducible, and can be used as preparative purposes [6-7]. Most analytical separations for enantiomers are performed by using chiral columns. However, there are fewer attempts to separate the diastereomers by using these type of columns [8]. There is a diastereomer separation method available either by using the silica gel on a column or diastereomeric ionic crystals, e.g., acid/amine, or inclusion complex crystals are fractionally recrystallized. Therefore, the development and application examples of the separation methods may have a crucial role in the progress of molecular chirality level and also to discover the difference in pharmacokinetic, pharmacodynamic, metabolic, and toxic properties between the diastereomers of drug-like compounds and precursors, and other biologically active compounds [9]. To date, many classes of chalcone type compounds have been described as precursors that have generated a range of plant metabolites, revealing interesting biological activities. They have developed by changing aromatic rings in the scaffold, synthetically wellestablished protocols and using extended $\pi$-conjugated systems. Among these ligands, there are only a few examples of chalcones bearing acenaphtene ring, but there is no study about the 
separation on chiral columns of diastereomers or the use of chiral additives in the mobile phase. This serious knowledge gap with various biological activities of chalcone rings prompted us to design and synthesis of novel (E,Z)-2-(4-aminobenzylidene)acenaphthylen-1(2H)-one, 4 and its separation on HPLC system with chiral column since these promising advances, chalcone-based science is expected to be applied in drug discovery [10-12].

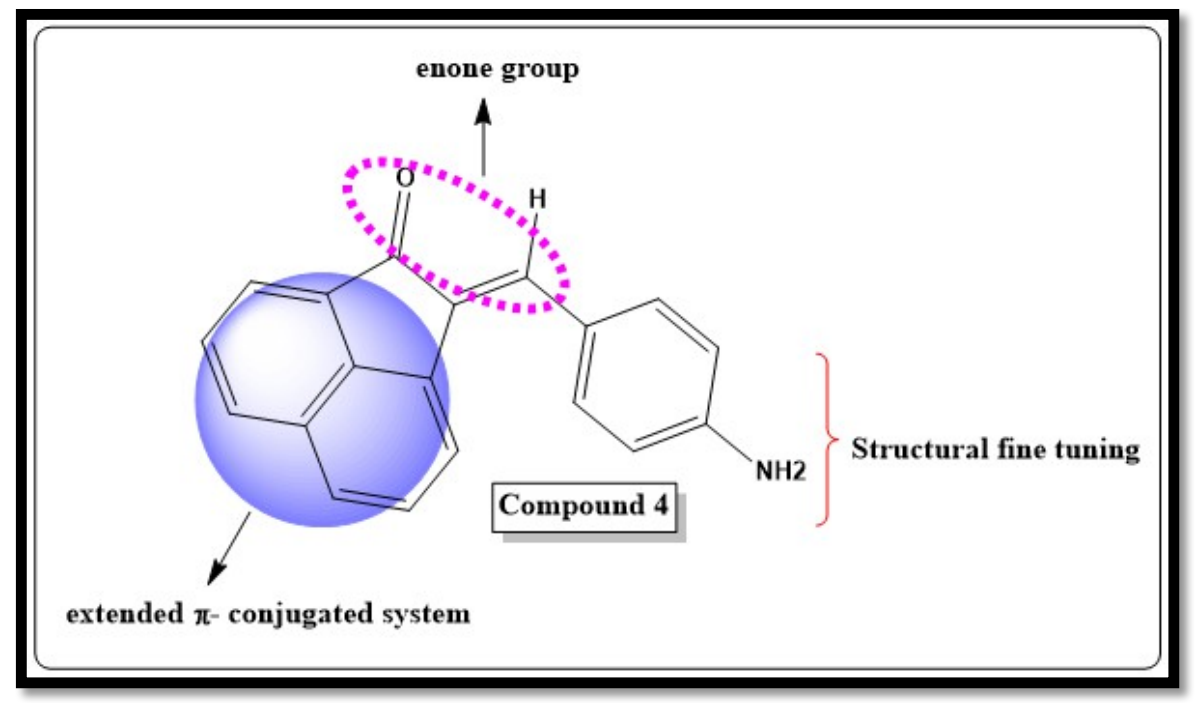

Figure 1: Design of chalcone compound 4

Herein, the author report a facile and versatile procedure for the synthesis of a chalcone derivate that a functionalized (E,Z)-2-(4-aminobenzylidene)acenaphthylen-1(2H)-one 4 and development of a HPLC method for the seperation of its diastereomers by using chiral column which contains the amylose tris(3,5-dimethylphenylcarbamate) as chiral selector.

\section{Materials and Methods}

\subsection{Sample preparation}

The Synthesis of 1-Acenaphtenone: 1-Acenaphtenone was synthesized by using literature methods with slight modification. 1-Naphtylacetylchlorid was obtained quantitative yield by using freshly distilled thionyl chloride and $3 \mathrm{~h}$ reflux and directly used for the next step [13].

The Synthesis of (E,Z)-2-(4-nitrobenzylidene)acenaphthylen-1(2H)-one, 3: Equivalent amounts of 1-acenaphtenone, and p-nitrobenzaldehyde are dissolved $20 \mathrm{~mL}$ ethanol. Subsequently, ethanolic solution (1.5 equivalent $\mathrm{KOH}$ in $5 \mathrm{~mL}$ ethanol) was added slowly to the reaction mixture and kept 24 hours at room temperature under stirring. During the period of reaction the color of mixture changes from yellow to dark red. The solution was added to ice water and neutralized 
with dilute $\mathrm{HCl}$. The precipitated solid was filtered and recrystallized twice from ethanol afforded compound 3. (Yield: $80 \%$, yellow solid); m.p. $243-245{ }^{\circ} \mathrm{C}$. lit: $240-242{ }^{\circ} \mathrm{C}$ [14].

The Synthesis of (E,Z)-2-(4-aminobenzylidene)acenaphthylen-1(2H)-one, 4: To a solution of compound 3 ( $1 \mathrm{mmol}, 301 \mathrm{mg}$ ) in $15 \mathrm{~mL}$ ethanol was added to $\mathrm{SnCl}_{2} \cdot 2 \mathrm{H}_{2} \mathrm{O}$ (4.6 mmol, $1.0 \mathrm{~g}$ ). The mixture was heated at $90{ }^{\circ} \mathrm{C}$ for $4 \mathrm{~h}$ by monitoring thin layer chromatography (TLC). After cooling to the room temperature, the reaction mixture was poured over ice to precipitate and treated with a $25 \%$ aqueous $\mathrm{NaOH}$ solution to adjust $\mathrm{pH}$ to 9 . The obtained residue was extracted with $2 \times 50 \mathrm{~mL}$ ethyl acetate, dried over $\mathrm{Na}_{2} \mathrm{SO}_{4}$, and evaporated to dryness. The solid was purified by column chromotography using ethyl acetate/n-hexane $(2: 1)$ as eluent to afford compound 4. ( Yield: \% 60 dark orange solid); m.p. $327-330{ }^{\circ} \mathrm{C}$. IR (KBr) $v_{\max }: 3427,3206,3041$, 2926, 2845, 1687,1517, 820, $770 \mathrm{~cm}^{-1} ;{ }^{1} \mathrm{H}$ NMR (400 MHz, DMSO- $\left.d_{6}\right): \delta 8.25$ (d, $J=7.0 \mathrm{~Hz}$, 1H), 8.11 (d, $J=7.1 \mathrm{~Hz}, 1 \mathrm{H}), 8.01$ (dd, $J=7.0,0.8 \mathrm{~Hz}, 1 \mathrm{H}), 7.97$ (d, $J=8.3 \mathrm{~Hz}, 1 \mathrm{H}), 7.90-7,80$ $(\mathrm{m}, 2 \mathrm{H}), 7.73-7,60(\mathrm{~m}, 3 \mathrm{H}), 6.73(\mathrm{~d}, J=8.6 \mathrm{~Hz}, 2 \mathrm{H}), 6.05(\mathrm{~s}, 2 \mathrm{H}) .{ }^{13} \mathrm{C}$ NMR (100 MHz, DMSO$\left.d_{6}\right): \delta 186,2,148.2,137.1,134.9,134.4,133.9,132.1,131.4,130.4,129.9,129.6,129.2,127.9$, 126.9, 125.7, 123.2, 115.6, TOF- MS (m/z), calcd for $\mathrm{C}_{19} \mathrm{H}_{14} \mathrm{NO}[\mathrm{M}-\mathrm{H}]^{+}, 272,1075$; found, 272,1046 .

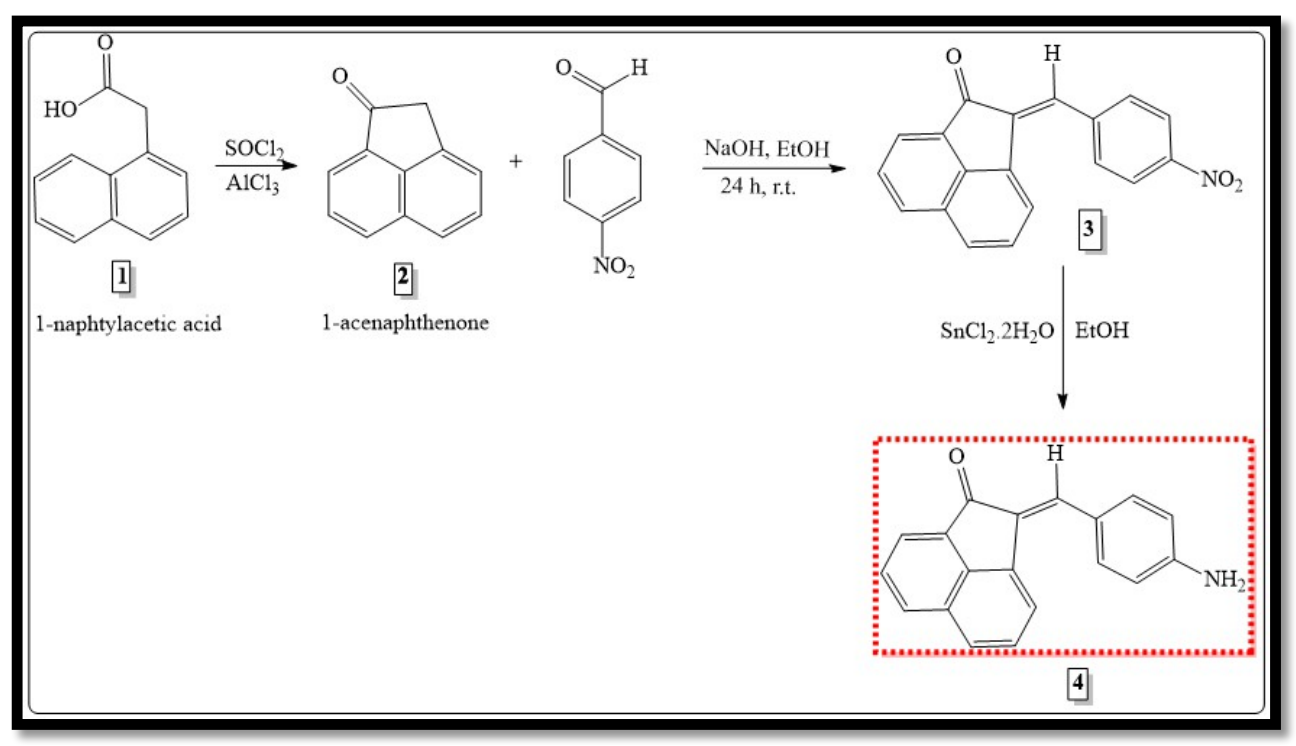

Figure 2: Synthetic routes to obtain compound 4

\subsection{Materials and methods}

All chemicals were purchased from commercial sources, and all of them are analytical grade. The progress of the reaction was monitored by TLC which was performed by using Merck 
silica gel (60 F254) plates $(0.25 \mathrm{~mm})$ and visualized under ultraviolet light (UV). The melting points were measured by using the Electrothermal IA9200 apparatus. FT-IR (ATR) spectra were recorded on Perkin-Elmer Spectrum 100 FT-IR spectrophotometer. NMR spectra were measured in DMSO- ${ }_{d \sigma}$ solvent with TMS as an internal standard. Chemical shifts are expressed in $\delta$ units (ppm on a Bruker Avance III $400 \mathrm{MHz}\left({ }^{1} \mathrm{H}: 400 \mathrm{MHz},{ }^{13} \mathrm{C}: 100 \mathrm{MHz}\right.$ ) NaNoBay FTNMR spectrometer at the Mersin University Advanced Technology Education, Research and Application Center (MEITAM). Coupling constants $(J)$ are given in hertz (Hz). The Mass spectrum was recorded by Agilent 6530 Accurate-Mass (Q-TOF LC/MS) in m/z (rel. \%).

The structure of the studied analyte is shown in Fig. 1. HPLC-grade n-hexane and isopropanol as well as chemical-grade formic acid, were supplied by Karl Roth (Karlsruhe, Germany). Chiral column included Amylose tris(3,5-dimethylphenylcarbamate) as CSP was provided by Phenomenex Inc. (Torrance, CA, USA). and the dimensions of the analytical column was of $250 \times 4.6 \mathrm{~mm}$ dimensions packed with silica particles of $5 \mu \mathrm{m}$ nominal particle size. An Agilent 1100 HPLC instrument (Agilent Technologies, Palo Alto, CA, USA) including the Chemstation software (version B.03.02-SR2) was used for instrument control, data acquisition, and data processing. HPLC separations were performed at $45{ }^{\circ} \mathrm{C}$ at $1.00 \mathrm{~mL} / \mathrm{min}$ mobile phase flow rate and $10 \mu \mathrm{L}$ injection volume if not mentioned otherwise. The mobile phases contained n-hexane : isopropanol, 60:40 (v/v). UV detection was performed at $225 \mathrm{~nm}$.

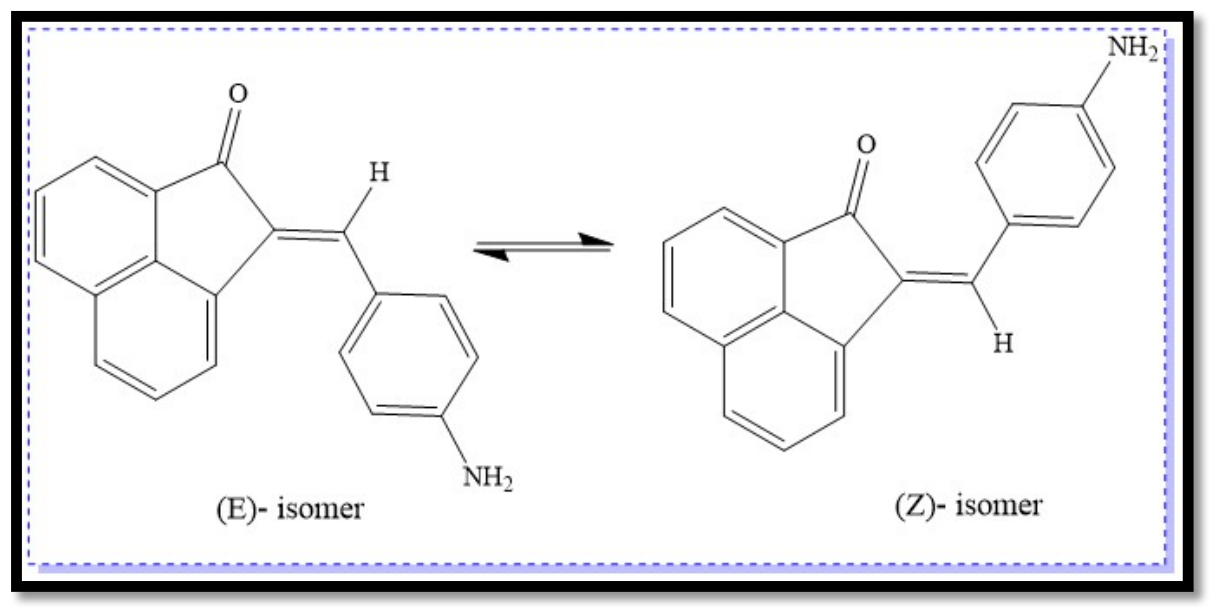

Figure 3: Diastereomeric forms of compound 4

\section{Results and Discussion}

\subsection{Ligand design and synthesis}


Synthetic access to the novel acenaphtenopyrimidine derivative compound 4 is outlined in Fig. 2. Compound 4 was synthesized from commercially available starting materials 1naphtylacetic acid (1) and thionyl chloride via ring closure by intramolecular FriedelCrafts reaction following reported procedures with slight modifications [13] Preparation of novel intermediate compound $\mathbf{3}$ was carried out via claisen schmidt condensation using 1acenaphthenone, $\mathbf{2}$ and p-nitrobenzaldehyde under the alkaline condition to obtain $80 \%$ yield. (E,Z)-2-(4-nitrobenzylidene)acenaphthylen-1(2H)-one 3 was readily reduced by $\mathrm{SnCl}_{2}, 2 \mathrm{H}_{2} \mathrm{O}$ in ethanol to afford compound 4 in $60 \%$ yield. All compounds were identified and fully characterized by FT-IR, NMR, and mass spectroscopy.

\subsection{Method development for the separation of diastereomers}

Several types of chiral selectors were used in the present study. The nature and the backbone of these chiral selectors have significantly affected the separation behaviour of the diastereomers. There was no separation obtained by using Lux Cellulose 2, Lux Cellulose 3, Lux i-Cellulose 5 and partially separation observed by using Lux Cellulose 4, Lux Amylose 1. Furthermore, the successful separation between the diastereomers achieved via Lux Amylose 2, Lux Cellulose 1 and immobilised version of Lux i- Amylose 1. In the chromatographic analysis, the resolution between the target analytes has priority before the detection and quantification. On the other hand, while solvent consumption is another problem, the analysis time should be reduced as much as possible. Because of this reason, Lux i-Amylose 1 column was selected for the further steps due to the elution time of the target analytes. After selecting the optimum stationary phase, mobile phase trials were realized to obtain better peak shapes as well as the shortest analysis time. As a mobile phase, composition alcohol-hydrocarbon mixtures (n-hexane : isopropanol) with varied percentages were tested. The amount of isopropanol changed from $20 \%$ to $40 \%$ and due to the increased resolution between the diastereomers with the decreased analysis time $40 \%$ was selected as an optimum condition. After optimizing the major parameters, minor ones such as the temperature of the column and the flow rate were arranged. The flow rate was changed from 1 $\mathrm{mL} / \mathrm{min}$ to $2 \mathrm{~mL} / \mathrm{min}$. As expected, the analysis time decreased significantly, but due to the high column backpressure, flow rate kept constant as $1 \mathrm{~mL} / \mathrm{min}$. Lastly, the effect of temperature on the separation was evaluated from $25-50{ }^{\circ} \mathrm{C}$. It was observed that when using higher temperatures the elution times of the analytes decreased with the increasing of the resolution. Because of this reason, $45{ }^{\circ} \mathrm{C}$ was selected for the further steps while there is no significant change between 45 and $50{ }^{\circ} \mathrm{C}$. After all of these optimization studies, the resultant chromatogram with the system suitability test parameter results were demonstrated in Fig. 4. and Table 1. A system suitability 
test is to prove that the method can provide results of acceptable precision and accuracy. In general, the performed method suitability is required at least two of these criteria.

Table 1: System suitability test parameters for the analytes

\begin{tabular}{ccc}
\hline Parameters & Isomer I & Isomer II \\
\hline Retention time (min) & 8.797 & 11.713 \\
Retention factor $\left(\mathrm{k}^{\prime}\right)$ & 2.258 & 3.338 \\
Theoretical plates numbers $(\mathrm{N})$ & 10320 & 10020 \\
Separation factor $(\alpha)$ & - & 1.478 \\
Resolution $(\mathrm{Rs})$ & - & 7.149 \\
Symmetry & 1.066 & 1.052 \\
Tailing factor $(\mathrm{Tf})$ & 1.101 & 1.091 \\
\hline
\end{tabular}

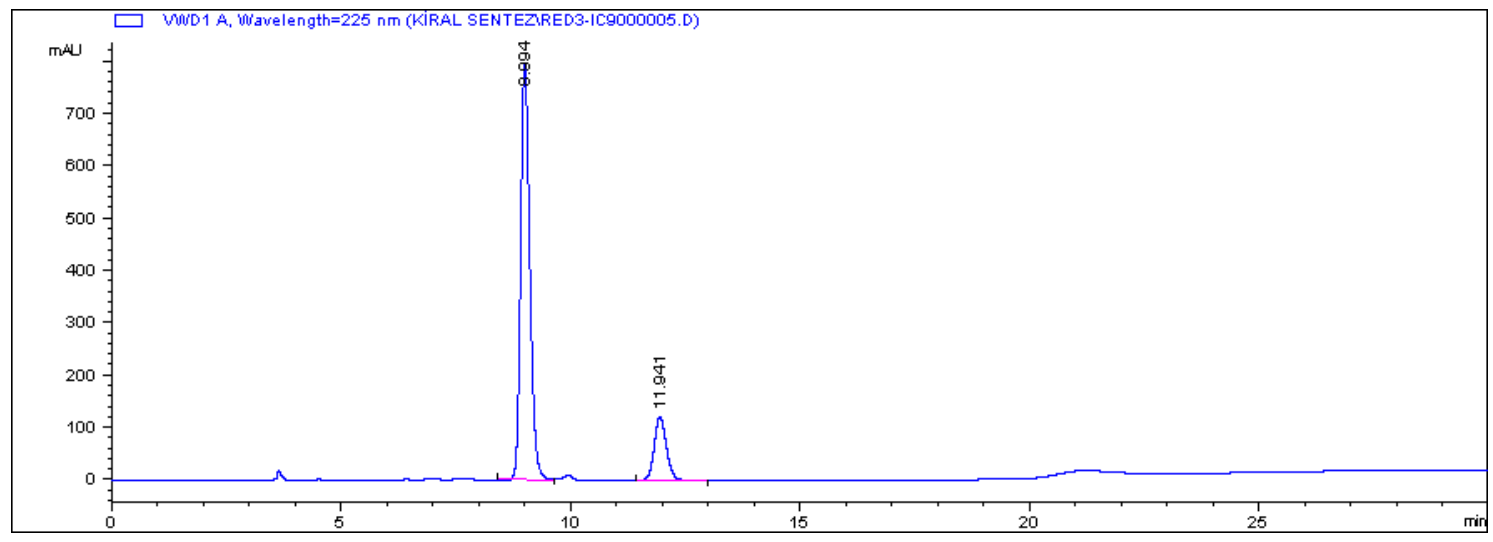

Figure 4: Chromatogram related with optimized conditions of Compound 4 isomers

\subsection{Method validation}

International Council on Harmonization (ICH) guidelines were used for the analytical method development and validation [15]. The validation of the methods were quantified for the isomers of Compound 4 with the following parameters: the limit of detection (LOD), limit of quantification (LOQ), accuracy, range, precision, specificity, linearity, etc. As for the raw compound 4, stock solutions were prepared by weighing $10 \mathrm{mg}$ solid and dissolving $10 \mathrm{~mL}$ in methanol. Standard solutions for HPLC were prepared by differentiating the concentration in the range between $1-250 \mu \mathrm{g} / \mathrm{mL}$. Calibration curve was created by plotting the peak area of the isomers of compound 4 to the concentration (Table 2). Biological samples were prepared similar to the raw materials with an additional step of protein precipitation by using methanol. After the precipitation step, the working standards of synthetic urine samples were applied to the system 
by dilute and shoot methodology. All results were demonstrated in Table 2, and the chromatogram related to the biological samples shown in Fig. 5.

Table 2: The obtained results from HPLC method

\begin{tabular}{ccccc}
\hline & \multicolumn{2}{c}{ Raw Material } & \multicolumn{2}{c}{ Biological Sample } \\
& Isomer I & Isomer II & Isomer I & Isomer II \\
\hline Linearity range $(\mu \mathrm{g} / \mathrm{mL})$ & $1-100$ & $1-100$ & $5-100$ & $5-100$ \\
Slope & 66.887 & 26.6 & 66.138 & 26.292 \\
Determination coefficient $\left(\mathrm{R}^{2}\right)$ & 0.999 & 0.9991 & 0.9993 & 0.9968 \\
Intercept & 71.658 & 49.991 & 80.941 & 68.102 \\
Limit of detection $(\mu \mathrm{g} / \mathrm{mL})$ & 0.06 & 0.2 & 0.56 & 1.25 \\
Limit of quantificatioin $(\mu \mathrm{g} / \mathrm{mL})$ & 0.19 & 0.59 & 1.67 & 3.75 \\
Within-day precision $(\mathrm{RSD} \%)$ & $<\% 5$ & $<\% 5$ & $<\% 5$ & $<\% 5$ \\
Added Amount & - & - & 10 & 10 \\
Found Amount & - & - & 10.56 & 10.54 \\
Recovery $(\%)$ & - & - & 105.65 & 105.46 \\
Bias & - & - & -5.65 & 5.46 \\
\hline
\end{tabular}

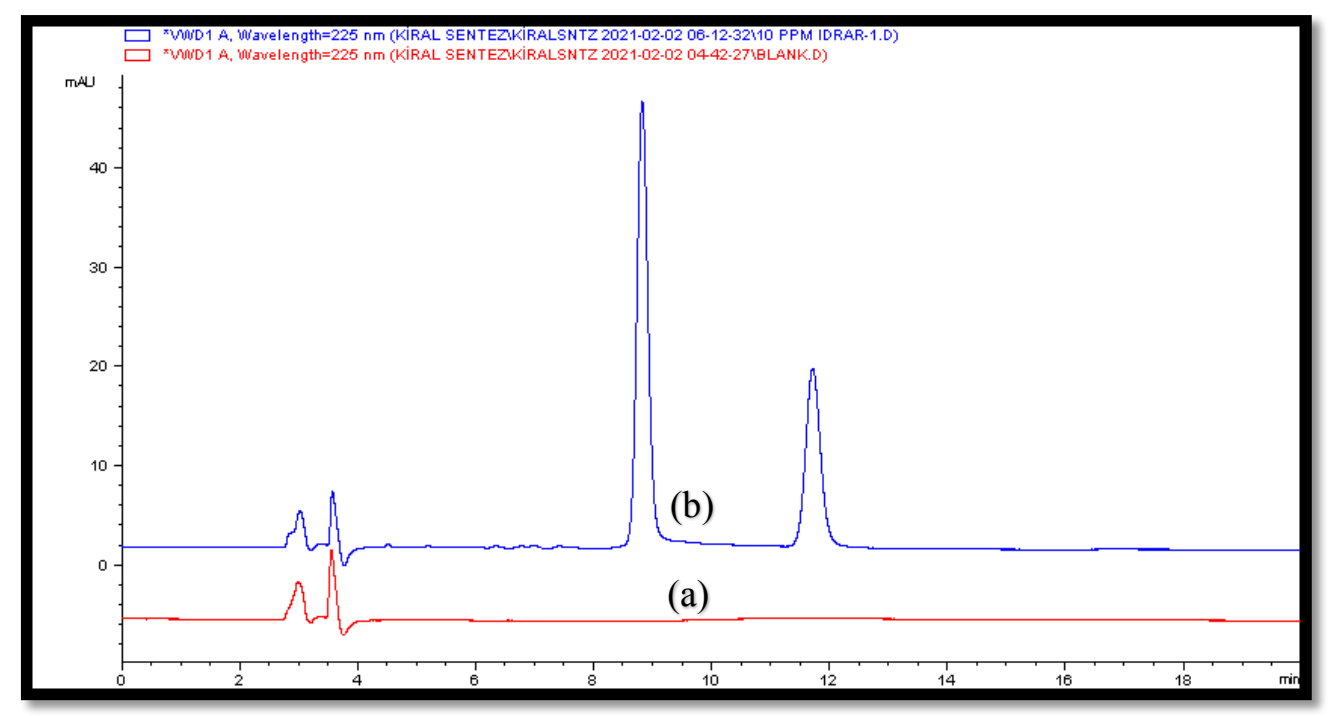

Figure 5: The HPLC chromatogram of the synthetic urine blank (a) and spiked with Compound 4 (b) (10 $\mu \mathrm{g} / \mathrm{mL})$

\section{Conclusion}

A novel chalcone derivate was prepared by using a facile and versatile procedure for the synthesis of a functionalized (E,Z)-2-(4-aminobenzylidene)acenaphthylen-1(2H)-one, $\mathbf{4}$, separated its diastereomers by using a chiral column that included amylose tris(3,5dimethylphenylcarbamate) as chiral selector. The developed HPLC method has come to the 
forefront since it presents a selective, sensitive, and accurate determination of chalcone diastereomers to contribute to the progress of chalcone-based drug discovery [16-20]. The optimized method was fully validated as per the ICH guidelines. High percentage recovery claims that the presented method was not affected by the impurities in the biological media. RSD\% values for the repeatability studies suggest that the optimized method was highly precise and reproducible.

\section{Acknowledgement}

I specially thank Prof. Dr. Zeynel SEFEROĞLU and Assoc. Dr. Mehmet GUMUSTAS for their help and support.

\section{References}

[1] Zhuang, C., Zhang, W., Sheng, C., Zhang, W., Xing, C., Miao, Z, Chalcone: a privileged structure in medicinal chemistry, Chemical Reviews, 117 (12), 7762-7810, 2017.

[2] De Mello, M.V.P., Abrahim-Vieira de A.B., Domingos, S.F.T., De Jesus, J.B., De Sousa, A.C.C., Rodrigues, C.R., De Souza, M.T.A., A comprehensive review of chalcone derivatives as antileishmanial agents, European Journal of Medicinal Chemistry, 150, 920-929, 2018.

[3] Yalçın, E., Kutlu, C.Y., Korkmaz, V., Şahin, E., Seferoğlu, Z., 2,6-Dicyanoaniline based donor-acceptor compounds: the facile synthesis of fluorescent 3, 5-diaryl/hetaryl-2, 6dicyanoanilines, ARKIVOC, 202-218, 2015.

[4] Yalçın, E., Achelle, S., Bayrak, Y., Seferoğlu, N., Barsella, A., Seferoğlu, Z., Styrylbased NLO chromophores: synthesis, spectroscopic properties, and theoretical calculations, Tetrahedron Letters, 56 (20), 2586-2589, 2015.

[5] Rammohan, A., Reddy, J. S., Sravya, G., Rao, C. N., Zyryanov, V.G., Chalcone synthesis, properties and medicinal applications: a review, Environmental Chemistry Letters, 18 (2), 433-458, 2020.

[6] Gogolashvili, A., Tatunashvili, E., Chankvetadze, L., Sohajda, T., Gumustas, M., Ozkan, A.S., Salgado, A., Chankvetadze, B., Separation of brombuterol enantiomers in capillary electrophoresis with cyclodextrin-type chiral selectors and investigation of structure of selector-selectand complexes using nuclear magnetic resonance spectroscopy, Electrophoresis, 40 (15), 1904-1912, 2019.

[7] Gumustas, M., Kurbanoglu, S., Uslu, B., Ozkan, A.S., UPLC versus HPLC on drug analysis: advantageous, applications and their validation parameters, Chromatographia, 76 (21), 1365-1427, 2013.

[8] Ahirrao, V., Vipul, R., Patil, K., More, K., Jadhav, R., Yeole, R., Reverse- phase chiral high-performance liquid chromatography for separation of a diastereomer in alalevonadifloxacin: A novel antibacterial agent, Biomedical Chromatography, 35 (6), e5079, 2021.

[9] Zhang, Z., Yang, G., Liang, G., Liu, H., Chen, Y., Chiral separation of Tamsulosin isomers by HPLC using cellulose Tris (3, 5-dimethhylphenylcarbamate) as a chiral stationary phase, Journal of Pharmaceutical and Biomedical Analysis, 34 (3), 689-693, 2004. 
[10] Pypowski, K., Uszyńska, I., Kluska, M., Chromatographic separation of isomers of tribenzylgermanium nitrile derivatives using chemically bonded aryl stationary phases, Journal of Liquid Chromatography \& Related Technologies, 29 (20), 2989-2996, 2006.

[11] Gumustas, M., Ozkan, A.S., Chankvetadze, B., Analytical and preparative scale separation of enantiomers of chiral drugs by chromatography and related methods., Current Medicinal Chemistry, 25 (33), 4152-4188, 2018.

[12] Gumustas, M., Kurbanoglu, S., Uslu, B., Ozkan, A.S., UPLC versus HPLC on drug analysis: Advantageous, applications and their validation parameters, Chromatographia, 76 (2122), 1365-1427, 2013

[13] Longstreet, A.R., Jo, M., Chandler, R.R., Hanson, K., Zhan, N., Hrudka, J.J., Hedi M., Shatruk, M., McQuade, D.T., Ylidenemalononitrile enamines as fluorescent "turn-on" indicators for primary amines, Journal of the American Chemical Society, 136 (44), 15493-15496, 2014.

[14] Charlesworth, E.H., Campbell, H., Conn, J.J., Elston, C.T., Stachiw, D.L., Some Acenaphtene Compounds, Canadian Journal of Chemistry, 35 (4), 351-357, 1957.

[15] ICH Harmonised Tripartite Guideline-Validation of Analytical Procedures: Text and Methodology, Available online:https://www.ema.europa.eu/en/ich-q2-r1-validationanalyticalprocedures-text-methodology(accessed on 4 May 2021), European Medicines Agency, Q2 (R1), 2014.

[16] Naresh, P., Pramodh, B., Naveen, S., Ganguly, S., Panda, J., Sunitha, K., Maniukiewicz, W., Lokanath, N.K., Cis and trans isomers of 1-(5-bromothiophen-2-yl)-3-(10chloroanthracen-9-yl) prop-2-en-1-one: Synthesis and characterization, Journal of Molecular Structure, 1236, 130228, 2021.

[17] Wang, M., Lin, L., Lu, J-J., Chen, X., Pharmacological review of isobavachalcone, a naturally occurring chalcone, Pharmacological Research, 165, 105483, 2021.

[18] Kumar, A., Kumar, S., Coumarin-chalcone hybrids for biological potentials: a strategy of molecular hybridization for drug design, International Journal of Pharmaceutical Sciences Review and Research, 64 (2), 146-151, 2020.

[19] Yalçin, E., Matković, M., Jukić, M., Obrova, L.G., Piantanida, I., Seferoğlu, Z., Novel fluorene/fluorenone DNA and RNA binders as efficient non-toxic ds-RNA selective fluorescent probes, Tetrahedron, 74 (5), 535-543, 2018.

[20] Pasricha, S., Gahlot, P., Synthetic strategies and biological potential of coumarinchalcone hybrids: a new dimension to drug design, Current Organic Chemistry, 24 (4), 402-438, 2020. 